\title{
Kajian Media Terhadap Pemberitaan Proses Legislasi Undang-Undang Cipta Kerja
}

\author{
M. Masad Masrur Buchori \\ Program Doktor Ilmu Komunikasi, Universitas Sahid Jakarta \\ Email: masadmasrur@gmail.com
}

\begin{abstract}
Framming of Mass Media in Indonesia, which tends to be pro towards the presence of the Job Creation Law, is considered not an actual articulation of the public interest (receiver) which it should represent. Theory, research, and even digital surveys involving the mass media as news subjects (channels) assess that the mass media are trapped in insignificant, normative news and do not accommodate counter opinions in an objective and balanced manner. The public then uses new media, especially social media, to mobilize a movement against the Job Creation Law, or to broadly mobilize pro-democracy forces through this movement. Although social media is not a mass media that applies measurable journalistic principles, social media offers digitization, convergence, interactivity, and development of network, which are considered more effective in articulating the true public interest in political communication towards the government as the messenger (sender).
\end{abstract}

Keywords: government; job creation law; mass media; social media

\begin{abstract}
Abstrak: Framming Media Massa yang cenderung bersikap pro terhadap hadirnya UU Cipta Kerja, dianggap bukan merupakan artikulasi yang sebenarnya terhadap kepentingan publik (receiver) yang seharusnya diwakilinya. Teori, penelitian, dan bahkan survei digital yang melibatkan media massa sebagai subjek pemberita (channel), menilai bahwa media massa terjebak pada pemberitaan yang tidak signifikan, normatif dan tidak mengakomodasi suara kontra secara obyektif dan berimbang. Publik kemudian menggunakan new media, khususnya media sosial, untuk menggalang gerakan kontra UU Cipta Kerja, atau secara luas menggalang kekuatan pro-demokrasi melalui gerakan ini. Meskipun media sosial bukanlah media massa yang menerapkan kaidah jurnalistik terukur, namun media sosial menawarkan digitisation, convergence, interactivity, dan development of network, yang dianggap lebih efektif mengartikulasi kepentingan publik yang sebenarnya dalam komunikasi politik terhadap pemerintah selaku penyampai pesan (sender).
\end{abstract}

Kata kunci: pemerintah; UU Cipta Kerja; media massa; media sosial

\section{Pendahuluan}

Pemerintah Indonesia berkehendak untuk masuk ke dalam lima besar kekuatan ekonomi dunia dengan menjadi negara berpendapatan tinggi pada tahun 2040. Hal tersebut tertuang dalam Visi Indonesia 2045. Pada dokumen RPJMN Bappenas Tahun 2020-2024, Pemerintah menargetkan pertumbuhan ekonomi rata-rata $6 \%$ dalam lima tahun ke depan, dan pertumbuhan PDB per kapita sebesar $+4 \%$. Dalam jangka panjang, transformasi ekonomi yang dilakukan pada tahun 2020-2024 akan membuat Indonesia keluar dari middle income trap di tahun 2036. Dengan rata-rata pertumbuhan ekonomi sebesar 5,7\% dan pertumbuhan PDB riil per-Kapita sebesar 5\%, pada tahun 2045 Indonesia diprediksi menjadi negara maju dengan ekonomi berkelanjutan, tingkat kemiskinan mendekati 0\%, dan memiliki tenaga kerja yang berkualitas (BPPN/Bappenas, 2019). 
Menghadapi tantangan ini, pemerintah fokus dalam mendorong pertumbuhan ekonomi melalui peningkatan investasi, salah satunya melalui peningkatan investasi dengan mereformasi regulasi di bidang perizinan berusaha. Reformasi ditujukan untuk menyelesaikan hambatan investasi seperti panjangnya rantai birokrasi, peraturan yang tumpang tindih, dan regulasi yang tidak harmonis terutama pada regulasi pusat dan daerah (hyper-regulation). Pada pelantikan Joko Widodo sebagai Presiden RI untuk periode 2019-2024, disampaikan bahwa pemerintah akan fokus mendorong pertumbuhan ekonomi melalui peningkatan investasi, salah satunya dengan mereformasi regulasi untuk menyelesaikan hambatan investasi, seperti rantai birokrasi yang panjang, tumpang tindih peraturan, dan regulasi yang tidak harmonis antara pusat dan daerah (hyper-regulation). Pemerintah akan menderegulasi peraturan dengan menerapkan metode omnibus law, dengan membentuk satu UU tematik yang mengubah berbagai ketentuan yang diatur dalam berbagai UU lain (NA RUU Cipta Kerja, 2019).

Pengajuan RUU Cipta Kerja dengan konsep/metode omnibus law mendapat pro dan kontra. Topik yang paling banyak disorot adalah keberpihakan pada investor, nasib pekerja, dan keselamatan lingkungan (dea.uii.ac.id, 2020). Gelombang kontra RUU Cipta Kerja meluas ketika dalam prakteknya, pembahasan RUU ini berlangsung cepat untuk ukuran sebuah RUU omnibus law yang meringkas puluhan UU ke dalam satu RUU. Proses penyusunan draf RUU Cipta Kerja dikhawatirkan hanya dilakukan oleh Pemerintah dan segelintir elite, seperti kepala daerah dan asosiasi pengusaha, sehingga mengurangi kualitas diskusi di masyarakat, dan meninggalkan kepentingan para buruh dan pekerja yang menjadi objek utama dalam pembahasan RUU ini (buruh.co, 2020). Tercatat, demonstrasi penolakan RUU Cipta Kerja, rusuh di beberapa daerah, seperti di Semarang, Jakarta, Yogyakarta, Surabaya, Bandung, Banten, Makassar, Bekasi, Malang, dan lain-lain. Unjuk rasa tersebut tidak hanya berlangsung satu atau dua kali, namun bergelombang pada hari-hari tertentu dan selalu menimbulkan kekhawatiran atas adanya kerusuhan.

Penolakan tentu bukan hanya terjadi di lapangan, namun juga muncul berbagai opini di media massa nasional maupun daerah, bahkan media internasional memberitakannya (wartaekonomi.co.id). Sebagaimana laporan Muhamad Heychael dan Purnama Ayu Rizky di remotivi.com, media massa tidak sepenuhnya mampu menjalankan perannya sebagai pembawa suara rakyat. Media memuat lebih banyak pernyataan pro ketimbang kontra RUU Cipta Kerja (remotivi.or.id, 2020). Menurut penelitian ini, media massa idealnya berpihak kepada masyarakat sipil, tetapi secara terukur, hanya $C N N T V$ yang memberi ruang lebih bagi wacana kontra UU Cipta Kerja. Media iNews dinilai lebih mengedepankan sentimen pernyataan yang lebih berimbang. Media diluar $C N N T V$ dan iNews, lebih banyak memberi pada wacana pro. 


\section{Sentimen Pernyataan Per Stasiun TV}

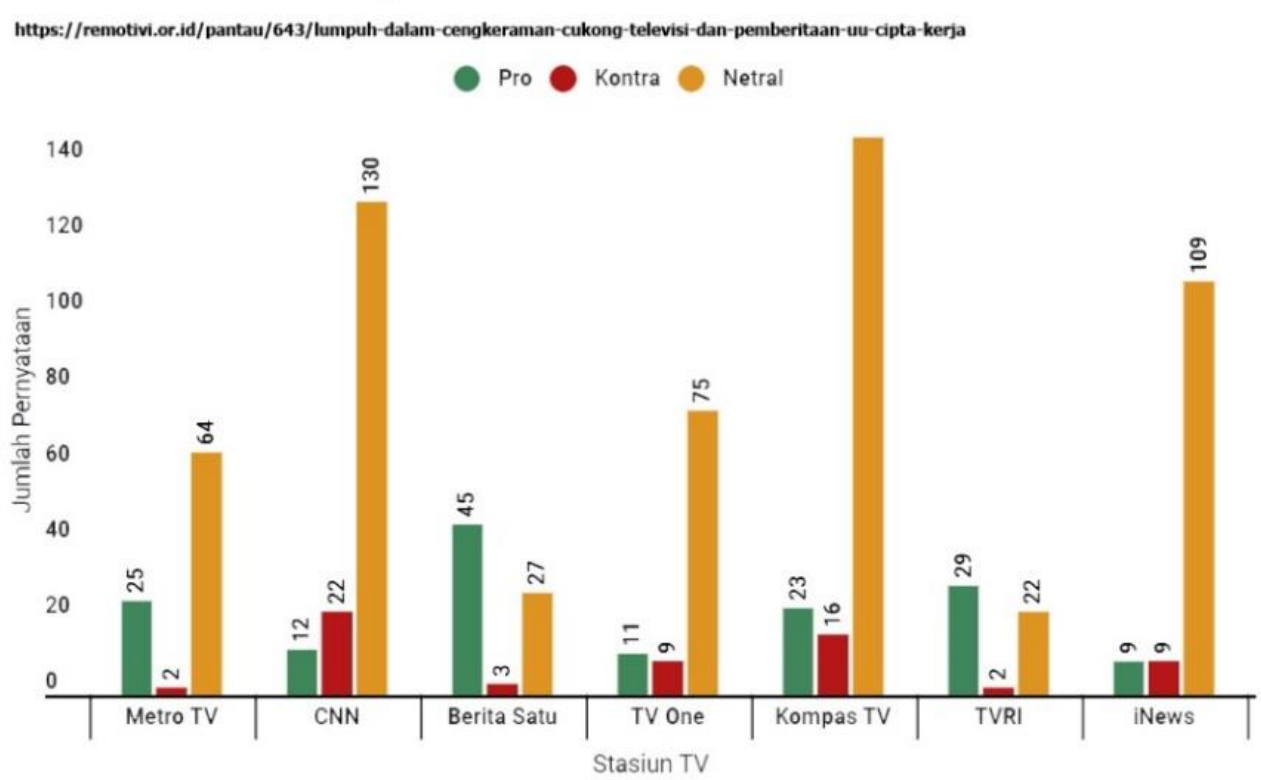

Sumber: remotivi.com

Omnibus law cenderung diberitakan secara positif, atau sekitar 52\% pada kategori media daring. Kompas.com, sekitar 22,9\% lebih banyak memberikan ruang bagi pernyataan menolak omnibus law, sementara empat media lain, memberikan ruang menolak omnibus law tidak lebih dari $17,5 \%$. Berita dengan sentimen negatif yang cukup minim, sekitar 16,4\%, menunjukkan bahwa topik omnibus law diberitakan dengan tidak mengakomodasi pendapat kontra secara berimbang. Indikasi minim akomodasi pendapat kontra omnibus law diperkuat melalui persentase sentimen netral yang lebih besar, sekitar 31,6\% dibanding sentimen negatif. Berita yang dikategorikan bersentimen netral adalah berita yang memuat pernyataan narasumber yang bersifat informatif, deskriptif, dan tanpa menunjukkan sikap secara eksplisit terhadap omnibus law (remotivi.or.id, 2020).

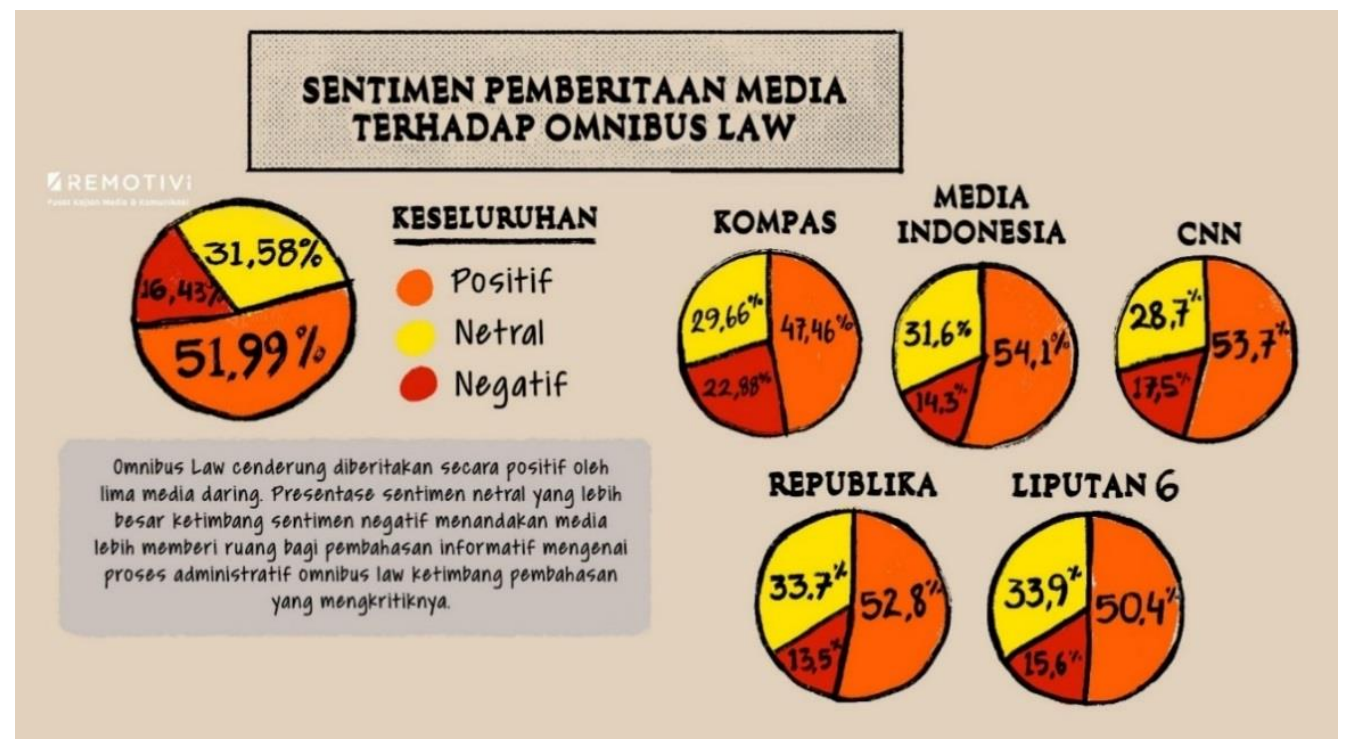

Sumber: remotivi.com 
Media sosial yang menjadi wilayah bebas bagi masyarakat (warganet/nitizen) untuk menyampaikan gagasannya, cukup marak dengan berbagai opini. Menurut Media Kernels Indonesia dan Data Center Badan Sistem Informasi (BSI) Universitas Islam Indonesia, RUU Cipta Kerja mendapat respon pro dan kontra dengan topik yang paling banyak disorot adalah keberpihakan pada investor, nasib pekerja, dan keselamatan lingkungan (dea.uii.ac.id, 2020). Perbincangan warganet (nitizen) sempat mengalami peningkatan pada 29 Februari, menurun pada 1-3 Maret, kemudian meningkat lagi pada hari berikutnya, dan kembali menurun pada 5 Maret 2020. Mayoritas warganet memberi tanggapan negatif terhadap RUU Cipta Kerja meskipun tanggapan positif sebanyak 32\% terhadap topik ini, terbilang cukup besar. Emosi marah dan kaget, menggambarkan sebagian besar perasaan warganet selain perasaan sedih, waspada, serta rasa percaya dan tidak percaya terhadap tujuan perancangan undang-undang ini.

Media Kernels Indonesia mengamati kata kunci omnibus law, omnibuslaw, atau cipta kerja di Twitter, Facebook, Instagram, dan Youtube. Sepanjang kurun waktu 9-16 Agustus 2020, total ada 121.234 mentions terkait omnibus law atau RUU Cipta Kerja. Perbincangan paling tinggi terjadi di Twitter dengan 110.816 mentions, disusul Instagram sebanyak (5.945), berita online (4.088), Facebook (368), dan Youtube (17). Adapun tagar terbanyak adalah \#JegalOmnibusLaw (11.623), \#tolakomnibuslaw (8.707), \#GagalkanOmnibusLaw (6,696), dan lainnya. Akun-akun yang mennyampaikan penolakan bukan cuma perorangan, salah satu komponen yang menolak omnibus law adalah Komnas HAM. Akun-akun yang dominan dalam menyuarakan masalah RUU Cipta Kerja ialah @wwwWINNERrrr (13.947 engagements), @FraksiRakyat_ID (5.387 engagements), @bintangwirayasa (4.016 engagements), @GreenpeaceID (3.602 engagements), dan @ podoradong (3.235 engagements).

Berdasarkan pada kondisi ini, praktis media sosial menjadi arena "pertarungan" antar berbagai pihak. Debat di sosial media bukan hanya terkait pembentukan opini, namun juga ajakan atau kampanye untuk mendukung omnibus law sebagai perlawanan balik atas aksi penolakan omnibus law. Kampanye tersebut diantaranya dilakukan oleh para artis, public figure, influencer dan buzzer media sosial dengan tagar \#IndonesiaButuhKerja melalui media video (hot.grid.id, 2020). Perdebatan antar warganet pun kemudian muncul dan menekan para artis dan influencer dan memaksa para influencer, buzzer dan pemerintah untuk berbicara soal kampanye dukungan ini. Meskipun pemerintah menyampaikan tidak menyediakan anggaran untuk membayar influencer dan yang dilakukan para influencer bisa jadi aksi sukarela, namun kepentingan di balik kampanye dukungan \#IndonesiaButuhKerja, amat dipertanyakan (cnnindonesia.com, 2020). Benarkah pemerintah sungguh menggunakan jasa para buzzer dan influencer dalam mengimbangi perdebatan terkait omnibus law di media sosial. Apakah pendapat warganet yang mendukung kebijakan pemerintah adalah buzzer mengingat mengemukakan pendapat secara terbuka, khususnya di media sosial, adalah hak seluruh warga.

Kecenderungan media massa konvensional, seperti televisi, majalah dan surat kabar, termasuk media daring, kepada sikap pro ketimbang kontra (RUU Cipta Kerja) perlu diteliti mengingat bahwa media massa perlu merepresentasikan kehendak publik. Mengapa media massa dirasa belum mewakili opini mayoritas publik terhadap masalah UU Cipta Kerja?

Fenomena "keberpihakan" media tersebut, memalingkan publik ke arah media baru, khususnya media sosial yang lebih memberikan peran bagi mereka dalam mengekspresikan pendapat dan opini. Masyarakat lebih memilih memperkuat/menyampaikan pendapat dan 
pandangannya terhadap RUU Cipta Kerja kepada jaringan yang mereka miliki ketimbang kepada media massa. Bagaimana resiko penggunaan media sosial sebagai media komunikasi politik dan menggalang dukungan publik jika media tersebut tidak memiliki kaidah jurnalistik yang terukur?

\section{Kajian Teori}

Kajian teori yang dikembangkan dari teori-teori kritis yang menunjukkan kepada persoalan-persoalan dasar media dalam pemberitaan terkait dengan isu sosial politik tentang penyusunan dan pengundangan RUU Cipta Kerja secara komprehensif dengan panduan nilai dan kaidah jurnalistik. Teori yang digunakan dalam menganalisis isu UU Cipta Kerja beorientasi pada penjelasan terhadap adanya konglomerasi media homogenisasi informasi yang menghalangi terciptanya demokratisasi ruang publik.

Penelitian terhadap pemberitaan media dan media sosial terkait masalah UU Cipta Kerja yang disajikan oleh laporan remotivi.com maupun Data Center Badan Sistem Informasi (BSI) dan Media Kernels Indonesia, dilakukan dengan secara teoritis dengan media sebagai pusat kajian (media-centric), dimana media massa sebagai penggerak utama perubahan sosial dengan tekanan pada perkembangan teknologi komunikasi yang tidak dapat dihindarkan.

Publik cenderung memanfaatkan dan mempercayai media sosial sebagai digital platform dalam menumpahkan memperoleh opini dan penolakan terhadap RUU Cipta Kerja. Media massa konvensional memuat lebih banyak pernyataan pro ketimbang kontra RUU Cipta Kerja menjadi kurang populer. Ketertarikan publik kepada media massa hanya pada pemberitaan-pemberitaan langsung terkait kerusuhan yang terjadi akibat demonstrasi penolakan RUU Cipta Kerja, karena peran media massa dianggap masih kurang berpihak pada publik, terutama kalangan buruh dan pekerja.

Memperhatikan ekspresi politik publik tersebut, menunjukkan bahwa dimensi teori pada kajian ini perlu difokuskan pada aspek budaya (cultural) dimana komunitas buruh dan pekerja teridentifikasi berusaha melakukan feedback sebagai pelaksanaan hak politik mereka. Ekspresi simbolik publik pada berbagai media, terutama media sosial seperti hastag penolakan UU Cipta Kerja, adalah ekspresi dari gagasan maupun makna dari komunitas pekerja. Ekspresi publik pro dan kontra atas diundangkannya UU Cipta Kerja ditekankan pada aspek humanistik, kualitatif, dan subjektif, yang merupakan ekspresi identitas komunal di tingkat lokal hingga pengaruh di tingkat global.

Perspektif pemberitaan media massa yang digunakan pada kasus UU Cipta Kerja ini adalah media materialis, dimana media yang diharapkan mampu menjadi pilar ke empat demokrasi, perlu menunjukkan kemampuannya di tengah iklim konglomerasi media. Pemberitaan media massa yang cenderung pro terhadap pengundangan UU Cipta Kerja, mengakibatkan pengalihan perhatian publik kepada penggunaan media sosial sebagai bentuk kekesalan publik yang cenderung berbeda kepentingan dan sikap atas kebijakan pengudangan UU Cipta Kerja.

\section{Metode Penelitian}

Metode penelitian kualitatif kajian media terhadap pemberitaan proses legislasi UU Cipta Kerja ini, digunakan metode studi literatur, jurnal, buku, serta konten analisis dari media massa yang dikaitkan dengan teknik analisa situasi konflik dari kacamata sosiolog Simon Fisher, Dekha Ibrahim Abdi, Jawed Ludin, Ricard Smith, Steve Williams, S.W (2001). 
Paradigma penelitian konflik gerakan masyarakat sipil dan pemerintah ini menggunakan paradigma kritis yang berdiskusi pada wilayah sejarah, erosi ketidaktahuan dan kesalahpahaman, yang merangsang tindakan. Menurut Guba dan Lincoln (1989), data dan informasi, diperoleh dengan menggunakan dari kumpulan sumber tertulis, buku, jurnal, arsip, artikel massa media, dan dokumentasi pendukung yang relevan. Observasi ini mengukur kebaikan/kualitas atau kriteria penelitian, dengan mengajukan sejarah ketetapan dengan memperhatikan sejarah, sosial, budaya, ekonomi, dan teks politik.

\section{Hasil dan Pembahasan}

Masalah pengundangan UU Cipta Kerja dalam komunikasi politik Lasswell ini, dianalisis pada saluran (media) yang digunakan sender kepada receiver. Media massa sebagaimana McQuail (2005), terjebak pada aspek praktik monopoli industri media massa yang berimbas pada penyeragaman konten. Di Indonesia ada 13 perusahaan raksasa yang menjadi pemain dalam inustri media, yang sudah terpolarisasi pada ideologi atau world view sebagai salah satu kerangka referensi yang dipakai untuk melihat realitas (Nugroho, dkk, 2012).

Lebih dalam lagi, jika kita lihat dari konstruksi media, konten media massa juga dilihat dari beberapa faktor yang termasuk dalam lingkungan di luar media, seperti sumber berita ataupun pihak eksternal. Berita bersentimen positif (pro UU Cipta Kerja) yang menghadirkan narasumber dari pemerintah (sekitar 66,3\%), pengusaha $(8,9 \%)$, dan parlemen $(8,1 \%)$, menunjukkan adanya indikasi bahwa pertama, pemerintah adalah pihak yang paling berkepentingan atas omnibus law; kedua, para pendukung UU Cipta Kerja mengutamakan kepentingan bisnis. Indikasi tersebut semakin jelas bila dilihat dari topik tertinggi yang dibahas para pendukung UU Cipta Kerja, yaitu sektor ekonomi (sekitar 54,9\%).

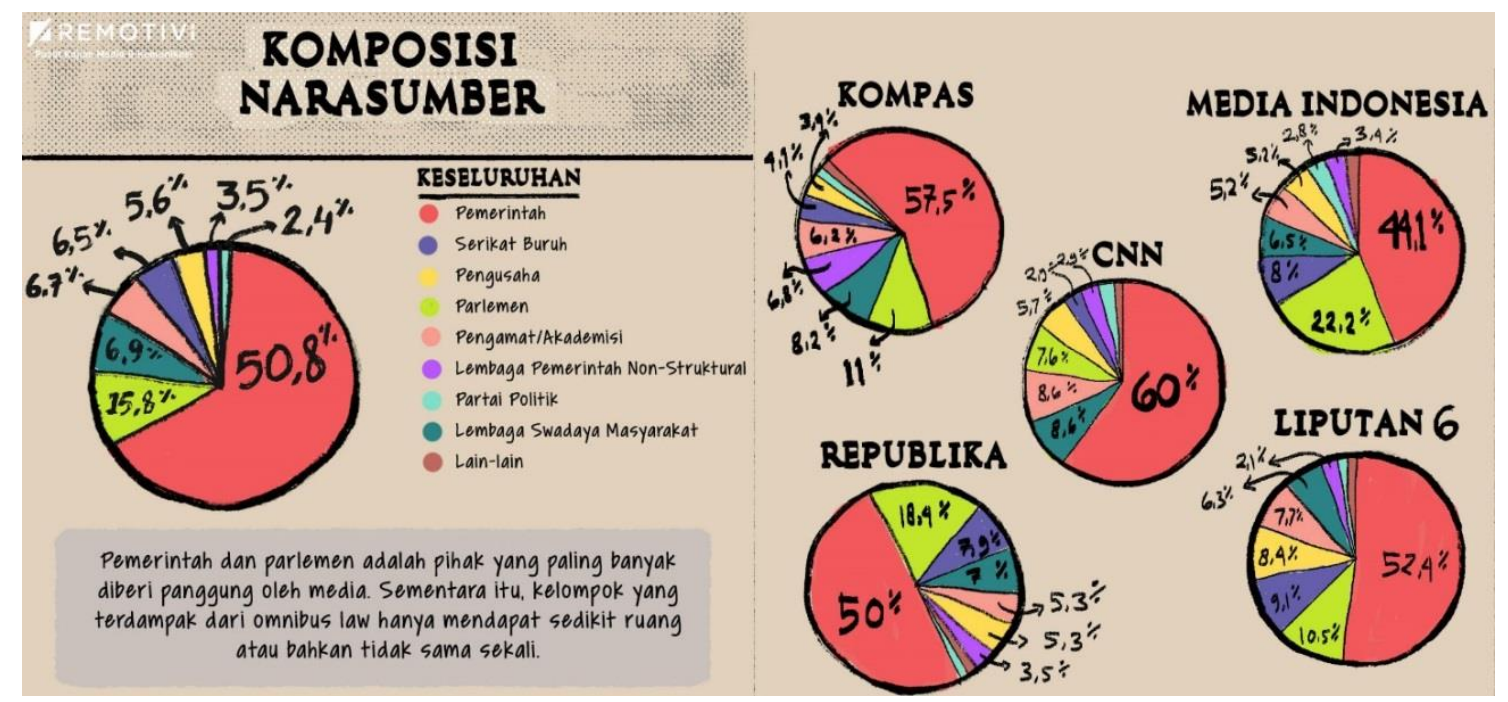

Sumber: remotivi.com

Data terakhir riset ini adalah berita bersentimen negatif yang didominasi oleh narasumber dari serikat buruh $(34,1 \%)$, LSM (22\%), dan pengamat (18,9\%). UU Cipta Kerja paling banyak dikritik dalam isu ketenagakerjaan $(31,9 \%)$, lingkungan hidup $(13,5 \%)$, dan proses legislasinya yang tidak transparan dan tidak partisipatif $(27,7 \%)$ (remotivi.or.id, 2020). 


\section{NARASUMBERDENGAN TOPIK BERSENTIMEN NEGATIF}

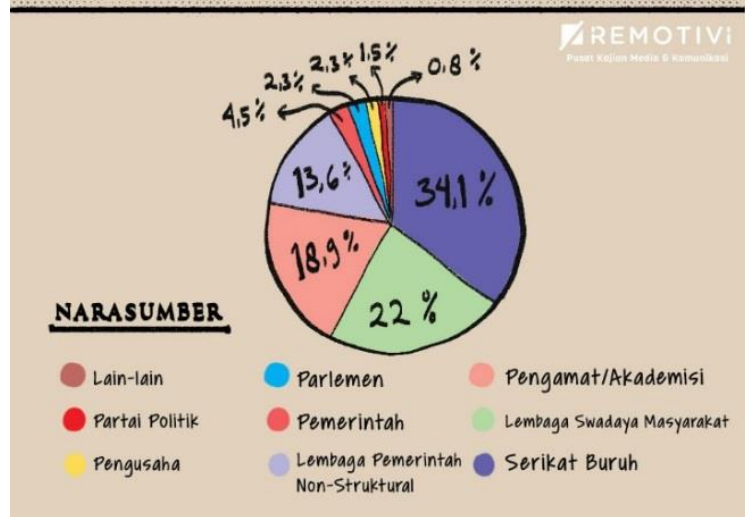

Omnibus Law dikritik paling banyak dalam isu ketenagakerjaan. lingkungan hidup dan proses legalisasinya yang tidak transparan dan partisipatif. Topik-topik bersentimen negatif yang berbeda dari topik-topik bersentimen positif mengindikasikan berbedanya aspirasi pemerintah dengan aspirasi buruh, LSM, dan pengamatlakademisi.

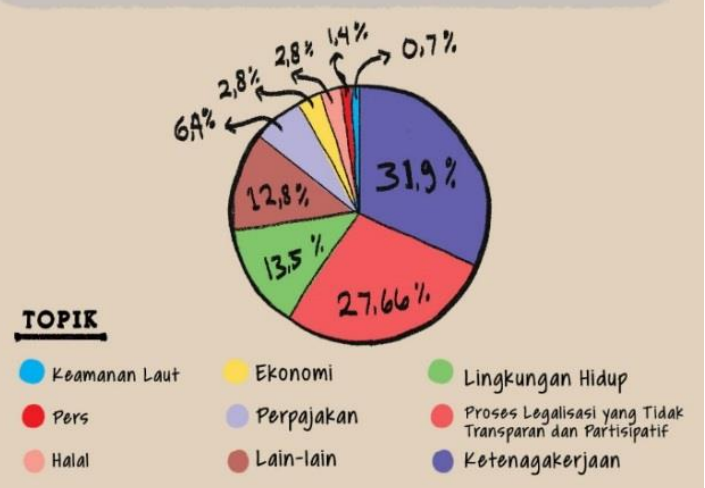

Sumber: remotivi.com

\section{NARASUMBER DENGAN TOPIK BERSENTIMEN POSITIF}

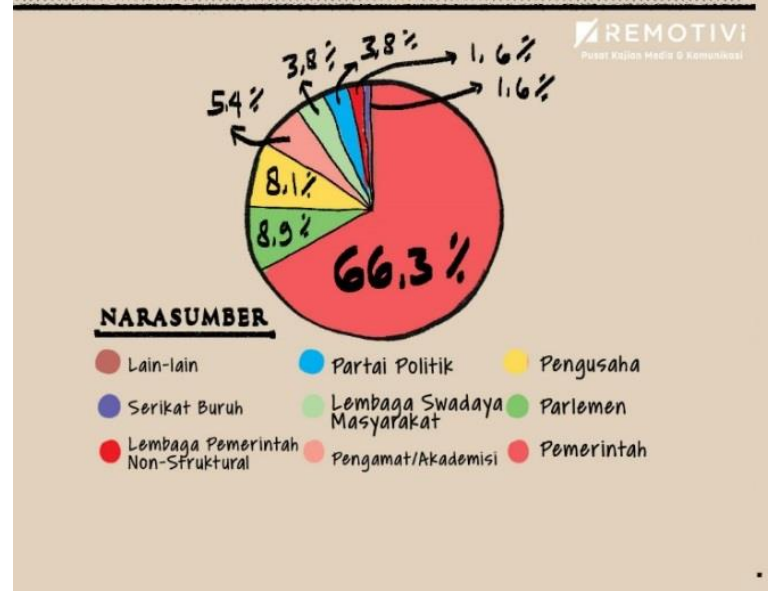

Dengan menjadi narasumber yang paling banyak berkontribusi pada sentimen positif pemberitaan atas Omnibus Law. pemerintah adalah pihak yang paling berkepentingan atas adanya produk hukum ini. Alasan peningkatan ekonomi dan pembukaan lapangan kerja menjadi strategi retoris yang menjustifikasi pemerintah untuk meloloskan Omnibus Law.

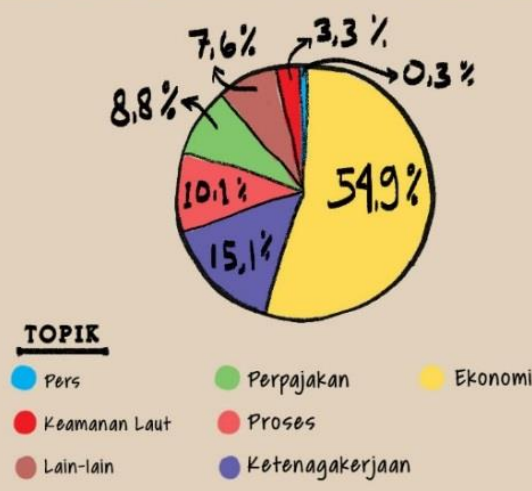

\section{Sumber: remotivi.com}

Data tersebut menunjukkan minimal dua hal. Pertama, dari komposisi narasumber bersentimen positif dan negatif tersebut tergambar bahwa komposisi pendukung UU Cipta Kerja cukup homogen sedangkan penolak UU Cipta Kerja lebih heterogen. Kedua, menurut sebaran topik pembahasan, masing-masing kelompok yang berbeda pendapat, memiliki aspirasi yang jauh berbeda. Hal ini mengindikasikan bahwa tidak tercipta dialog antara kubu pendukung dan penentang karena masing-masing membicarakan hal yang berbeda.

Pada hari Senin, 5 Oktober 2020, DPR RI resmi mengesahkan UU Cipta Kerja. Sejak pertama kali diusulkan pada 17 Desember 2019 dan masuk dalam 248 Prolegnas Jangka Menengah 2020-2024, RUU Cipta Kerja sudah mendapatkan banyak kritik dari publik. Demonstrasi warga pada 10 dan 13 Oktober 2020 menyambut pengesahan RUU ini. Petisi Tolak Cipta Kerja pada change.org mendapatkan lebih dari satu juta tanda tangan. Liputan demonstrasi 
penolakan dan talkshow yang mengangkat pro dan kontra RUU Cipta Kerja banyak ditampilkan di berbagai media massa. Pemberitaan ini banyak ditayangkan mengingat kebijakan terkait UU Cipta Kerja memiliki dampak yang sangat luas, baik terhadap sektor ketenagakerjaan, lingkungan, investasi, dan lain-lain.

Terkait persoalan RUU Cipta Kerja ini, media seharusnya mampu mewadahi perdebatan gagasan, namun, sebagaimana hasil penelitian https://remotivi.or.id/pantau, media massa terbukti mengecilkan suara kritis terhadap RUU Cipta Kerja. Media dianggap hanya memberitakan hal-hal yang normatif dan tidak signifikan.

Hal ini sebenarnya tidak mengherankan, mengingat monopoli dan dampak kepemilikan media, menghilangkan kepentingan dan kebebasan dalam ruang publik (public sphere). Konvergensi media berdampak makro pada konglomerasi media. Teori Normatif menghendaki bahwa media massa harus bebas dari kontrol pemerintah atau kelompok kepentingan tertentu, kalaupun media massa dapat lebih bebas dari kontrol pemerintah, namun tetap sulit bagi media untuk bebas dari kontrol kelompok kepentingan yang kuat baik dari sisi ekonomi maupun politik (Karman, 2014).

Sebagaimana teori agenda-setting, media massa memang telah menyusun dan menentukan agenda pembentuk gambaran atau isu yang penting dalam pikiran masyarakat bahwa RUU Cipta Kerja merupakan isu utama yang harus dilihat sebagai bagian utama yang harus disikapi oleh publik. Namun, masing-masing media memliki framming yang berbeda yang dapat dilihat dari sentimen berita yang disampaikan. Pemberitaan dengan sentimen negatif yang minim, sekitar 16,4\%, menunjukkan bahwa tema tentang RUU Cipta Kerja ini disampaikan tanpa mengakomodasi suara kontra secara berimbang. Indikasi tersebut didukung oleh prosentase sentimen netral yang lebih besar, atau sekitar 31,6\% dibanding sentimen negatif. (remotivi.or.id, 2020). Prosentase yang tinggi bagi sentimen netral menandakan bahwa media memberi ruang lebih bagi pembahasan informatif mengenai proses administratif omnibus law daripada memediasi ragam gagasan. Komposisi narasumber yang diundang menyampaikan pendapat di berbagai media massa seperti pemerintah $(50,8 \%)$ dan parlemen $(15,8 \%)$ merupakan pihak-pihak banyak diberi ruang oleh media massa. Kelompok yang terdampak RUU Cipta Kerja mendapat sedikit ruang atau bahkan tidak mendapat sama sekali ruang pendapat. Hal tersebut terlihat dari pelibatan kelompok buruh sebagai narasumber yang hanya sekitar 6,5\%. Pemberian ruang berbicara yang besar bagi pemerintah, menunjukkan kecenderungan peran media yang seolah sebagai jurubicara kepentingan pemerintah (remotivi.or.id, 2020).

Melihat kasus seperti ini, kita dapat berkaca pada ajakan Brendan Nyhan dan John Sides pada artikelnya di Journal the Forum Volume 9, yang menyampaikan bahwa para jurnalis seharusnya dapat menimba ilmu dari science politik tanpa harus melepaskan peran profesionalnya sebagai orang yang menulis cerita menarik tentang peristiwa terkini (Nyhan \& Sides, 2011). Bahkan Brendan dan Sides mengusulkan pendekatan yang akan membawa lebih banyak ilmu politik ke jurnalisme sambil menghormati norma profesional dan batasan organisasi organisasi berita. Politik sebagai science, sebenarnya mengarahkan dunia politik ke arah penguatan partisipasi publik dalam pengambilan keputusan bersama. Semakin sedikit partisipasi publik, kualitas keputusan politiknya akan makin minim. Media berperan memperluas partisipasi tersebut, namun jika media tidak mampu mewadahi pendapat mayoritas publik, maka media perlu belajar science politik dalam menyampaikan content beritanya.

Khalaf Tahat pada artikelnya di Journalism and Mass Communication, yang meneliti tentang profesionalitas yang dikembangkan Al Jazeera, menyimpulkan bahwa isi berita sangat 
termasuk visi dan misi media (Tahat, 2016). Pada penelitiannya, Khalaf menyatakan untuk sebuah organisasi media untuk dapat menjalankan misi demokrasinya membutuhkan lingkungan inkubator yang baik dan mengakomodasi kebebasan berekspresi. Profesionalisme jarang menyebar di negara atau masyarakat di mana media dijalankan dan dikendalikan oleh pemerintah, seperti di Cina, Rusia, dan Timur Tengah, namun Al Jazeera adalah pengecualian, hal ini karena Emir Qatar melakukan reformasi besar-besaran untuk mengakomodasi dan memfasilitasi peran Al Jazeera dalam membentuk dan mengarahkan orang Arab pada kesadaran demokrasi.

Kasus UU Cipta Kerja, dimana publik lebih mencurahkan feedback dan opininya melalui media sosial, sebenarnya juga terjadi di beberapa negara di berbagai belahan dunia. Marius Johannsen dalam artikelnya di International Journal of Public Information System (IJPIS), menyampaikan bahwa genre media sosial, dibantu oleh fungsionalitas platform digital, bergerak menuju kedewasaan, dengan aturan dan regulasinya sendiri. Media sosial sebagai ranah publik, berdiri kontras dengan wacana dominan yang dipimpin oleh elit berkuasa, sehingga membentuk ruang publik alternatif, yang memberi ruang untuk suara-suara yang berlawanan. Melalui surat kabar mereka mempresentasikan argumen rasional untuk meyakinkan masyarakat umum; di media sosial retorikanya lebih kuat, bertujuan untuk menjaga semangat tetap tinggi dan mengajak orang untuk berpartisipasi dalam demonstrasi (Johannsen, 2015). Hal tersebut juga didukung oleh Aborisade Philip Olubunmi di Online Journal of Communication and Media Technologies (Olubunmi, 2016), maupun Pallavi Mishra di Journal of Critical Reviews (Mishra, 2020). Paparan yang mereka sampaikan relevan dengan kasus "migrasi opini publik kontra RUU Cipta Kerja” dari media massa ke media sosial.

Debat di sosial media bukan hanya terkait pembentukan opini, namun juga ajakan atau kampanye untuk mendukung omnibus law sebagai perlawanan balik atas aksi penolakan omnibus law. Kampanye tersebut diantaranya dilakukan oleh para artis, public figure, influencer dan buzzer media sosial dengan tagar \#IndonesiaButuhKerja melalui media video (Mishra, 2020). Kampanye untuk mendukung omnibus law langsung dicurigai sebagai bentuk hembusan/dengungan pemerintah agar opini di emdia sosial lebih berimbang daripada sekedar penolakan RUU. Kubu kontra RUU Cipta Kerja pada langkah selanjutnya "mengkonsolidasikan diri" agar tidak terpancing kasus para influencer dan buzzer tersebut. Sambil membongkar kejujuran pemerintah atas penempatan buzzer dan influencer sebagai salah satu garda terdepan dalam menyampaikan informasi ke publik, mereka berusaha tetap berada di koridor "perlawanan".

Terkait berita hoaks dan peran buzzer di media sosial ini, Marius Johannsen melihat bahwa hal tersebut dapat diminimalisir melalui peran organisasi publik di media sosial yang terbentuk oleh komunitas nitizen yang sadar terhadap kepentingan politik mereka (Johannsen, 2015). Hal tersebut, sebagaimana dilakukan oleh para genre politik demokrasi di Norwegia, dapat membawa arah opini publik lebih fokus pada isu-isu yang menjadi concern publik, sehingga komunikasi politik dapat lebih efektif.

Littlejohn dan Karen A. Foss (2008) menyampaikan beberapa teori new media pada tradisi sociocultural. Mark Poster sebagaimana Littlejohn dan Karen A. Foss (2008), memang menyebutkan ada dua pandangan yang dominan tentang perbedaan antara era media pertama (old media) dengan penekanannya pada penyiaran, dan media kedua (new media) dengan penekanannya pada jaringan. Kedua pandangan tersebut adalah pendekatan interaksi sosial (social interaction), yang membedakan media menurut seberapa dekat media dengan model 
interaksi tatap muka; dan pendekatan integrasi sosial (social integration) yang menggambarkan media bukan dalam bentuk informasi, interaksi, atau bagaimana cara manusia menggunakan media sebagai cara menciptakan masyarakat. Ketika new media (media baru) hadir dengan tawaran digitisation, convergence, interactiviy, dan development of network, peran media sosial atau media interaktif terbukti lebih efektif dalam komunikasi sosial dan komunikasi politik. (Terry Flew, 2002). Pada kasus RUU Cipta Kerja, kecenderungan percaya terhadap media baru lebih tinggi daripada kepada media massa mainstream.

Kasus kekerasan yang terjadi pada saat penolakan RUU Cipta Kerja membuktikan bahwa media mainstream pun memporsikan paling besar dari pernyataan netral pada berita-berita yang menyoroti peristiwa demonstrasi. Topik pernyataan paling dominan dalam berita demonstrasi adalah "vandalisme" (26,7\%) sementara pernyataan yang memberi ruang pada aspirasi yang diusung dalam demonstrasi hanya 9,4\% (remotivi.or.id, 2020). Fakta ini menunjukkan pada kita bahwa apa yang menarik bagi kebanyakan media massa adalah peristiwa demonstrasi itu sendiri. Tepatnya, sensasionalisme liputan, bukan substansi penolakan.

\section{Kesimpulan}

Kecenderungan media massa kepada sikap pro ketimbang kontra (RUU Cipta Kerja), menunjukkan watak atau "ciri khas"-nya: tidak mampu sepenuhnya mengartikulasikan kepentingan publik yang seharusnya diwakilinya. Hal ini sudah diramalkan oleh teori, penelitian, dan bahkan survei digital sebagaimana dilakukan https://remotivi.or.id/pantau, bahwa media massa cenderung terjebak dalam memberitakan hal yang normatif dan tidak signifikan. Omnibus law cenderung disampaikan secara positif oleh media dan pemberitaaan dengan sentimen negatif yang minim menandakan bahwa topik RUU Cipta Kerja disampaikan dengan tidak mengakomodasi suara kontra secara berimbang.

Media adalah pembentuk konstruksi sosial misalnya melalui keberpihakan media, agenda media, hingga pembentukan konstruksi realitas. Hal tersebut tentu berpengaruh pada agenda setting mereka yang ditunjukkan melalui framing yang diciptakan melalui berita-berita yang ditampilkan. Ketika pemberitaan yang disampaikan media kurang mewakili dan memenuhi kehendak publik, akibatnya antara lain, publik berpaling ke arah media sosial yang lebih memberikan peran bagi mereka dalam mengekspresikan pendapat dan opini.

Publik yang merasa kepentingannya belum maksimal terartikulasi melalui media massa, menggunakan new media, khususnya media sosial, karena ia hadir dengan tawaran digitisation, convergence, interactivity, dan development of network. Peran praktis inilah yang mampu menggalang kekuatan dan dukungan terhadap gerakan penolakan RUU Cipta Kerja. Meskipun bukan merupakan media massa dengan kaidah jurnalistik terukur, efektifitas media sosial dalam menggalang gerakan pro-demokrasi di berbagai negara, turut mendorong pelaku, komunitas buruh dan pekerja khususnya, memanfaatkan media sosial. Namun, ranah media sosial yang awalnya didominasi oleh opini penolakan RUU Cipta Kerja juga "diserbu” oleh influencer dan buzzer yang diharapkan oleh pihak tertentu mampu menyeimbangkan opini. Kubu kontra RUU Cipta Kerja pada langkah selanjutnya "mengkonsolidasikan diri" agar tidak terpancing pada influencer dan buzzer, termasuk berita hoaks yang dominan di media sosial tersebut. Sambil membongkar kejujuran pemerintah atas penempatan buzzer dan influencer sebagai salah satu garda terdepan dalam menyampaikan informasi ke publik, mereka berusaha tetap berada di koridor "perlawanan". 
Penggunaan media sosial tanpa kaidah jurnalistik yang baku sangat beresiko, namun peran media sosial atau media interaktif di beberapa negara terbukti efektif dalam komunikasi sosial dan komunikasi politik, cukup disadari sehingga ranah media sosial menjadi menarik diperebutkan oleh opini pro dan kontra terhadap RUU Cipta Kerja.

\section{Daftar Pustaka}

Fisher, Simon., Dekha Ibrahim Abdi, Jawed Ludin, Ricard Smith, Steve Williams, S.W., 2001, Mengelola Konflik Ketrampilan dan Strategi untuk Bertindak, Jakarta: The British Council, Indonesia.

Guba, E. G., \& Lincoln, Y. S. (1989). Fourth Generation Evaluation. Newbury Park, CA: Sage. Https://Dea.Uii.Ac.Id/User/Lihat_Publikasi/Mengurai-Benang-Kusut-Omnibus-Law diakses 13

September 2020.

Https://Buruh.Co/Ruu-Cipta-Kerja-Awal-Langkah-Penuh-Masalah/ diakses 5 September 2020.

Https://www.wartaekonomi.co.id/read307654/demo-buruh-tolak-uu-cipta-kerja-ramaikan-mediamassa-internasional

Https://remotivi.or.id/pantau/643/lumpuh-dalam-cengkeraman-cukong-televisi-dan-pemberitaanuu-cipta-kerja

Https://remotivi.or.id/pantau/576/omnibus-law-media-menjadi-humas-pemerintah

Https://Dea.Uii.Ac.Id/User/Lihat_Publikasi/Mengurai-Benang-Kusut-Omnibus-Law diakses 13 September 2020.

Https://Mediakernels.Com/2020/08/17/Drone-Emprit-Kontra-Omnibus-Law-Di-Medsos-LebihBesar-Ketimbang-Yang-Pro/ diakses 13 September 2020.

Https://Hot.Grid.Id/Read/182291826/Lawan-Arus-Perjuangan-Para-Buruh-Dan-PekerjaInfluencer-Dan-Artis-Promotor-Omnibuslaw-Kicep-Usai-Didesak-Rakyat-UjungUjungnya-Minta-Maaf-Dan-Klarifikasi-Basi?Page=All diakses 13 September 2020. Https://Www.Cnnindonesia.Com/Nasional/20200814142219-32-535782/Artis-Di-Pusaran-Ruu-

Ciptaker-Penumpul-Kritik-Peredam-Demo diakses 13 September 2020.

Http://id.wikipedia.org/wiki/Media_sosial

Http://inet.detik.com/read/2014/11/03/101334/2736992/398/sebangsa-jejaring-sosial-yangindonesia-banget.

Https://remotivi.or.id/pantau/576/omnibus-law-media-menjadi-humas-pemerintah

Https://Remotivi.Or.Id/Pantau/643/Lumpuh-Dalam-Cengkeraman-Cukong-Televisi-Dan-

Pemberitaan-Uu-Cipta-Kerja

Https://Hot.Grid.Id/Read/182291826/Lawan-Arus-Perjuangan-Para-Buruh-Dan-Pekerja-

Influencer-Dan-Artis-Promotor-Omnibuslaw-Kicep-Usai-Didesak-Rakyat-Ujung-

Ujungnya-Minta-Maaf-Dan-Klarifikasi-Basi?Page=All diakses 13 September 2020.

Https://remotivi.or.id/pantau/643/lumpuh-dalam-cengkeraman-cukong-televisi-dan-pemberitaanuu-cipta-kerja

Johannsen, Marius Rohde., (2015) New vs Old Media: A Case Study of Political Protest Groups Media Use in A Norwegian Municipality, International Journal of Public Information System (IJPIS), Vol 1, 2015.

Karman, K., (2014). Riset Penggunaan Media Dan Perkembangannya Kini. Jurnal Penelitian Komunikasi 17 (2), 2014. 1, 2014.

Karman, (2014) Monopoli Kepemilikan Media \& Lenyapnya Hak Publik, Jurnal Masyarakat Telematika dan Informasi Vol. 5 No. 1 Juni 2014. 
Kementerian BPPN/Bappenas, 2019, Rancangan Teknokratik RPJMN 2020-2024: Indonesia Berpenghasilan menengah-tinggi yang sejahtera, adil, dan berkesinambungan, Kementerian BPPN/Bappenas, 2019 (Versi 14 Agustus 2019).

Littlejohn, S.W \& Karen A. Foss. 2008, Theories of Human Communication,9th Edition, Belmont, California: Thomson Wadsworth Publishing Company.

McQuail's, Denis. (2005). Mass Communication Theory, London: SAGE Publications.

Mishra, Pallavi., (2020). Restructuring Mainstream Journalism: A Comparative Study Of Traditional And New Media Concepts, Journal of Critical Reviews, Vol 7, Issue 12, 2020.

Naskah Akdemik RUU Cipta Kerja yang dapat diakses di website resmi Kemenko Perekonomian (www.ekon.go.id).

Nugroho, Yanuar., Putri, Dinita Andriani., dan Laksmi, Shita. (2012). Mapping the landscape of the media industry in contemporary Indonesia. Jakarta: Ford Foundation.

Nyhan, Brendan., dan Sides, John., (2011). How Political Science Can Help Journalism (and Still Let Journalis Be Journalist), Journal The Forum Volume 9, Isuue 1, 2011.

Olubunmi, Aborisade Philip, (2016). The Emerging Cyber Media: The beginning of a New Media and the end of Old Media, Online Journal of Communication and Media Technologies Volume: 6 - Issue: 1 January - 2016.

Tahat, Khalaf., (2016). An International Journalism Model of Professionalism in News Production: The Concepts and the Measurements, Journalism and Mass Communication, Volume 6, Number 4, April 2016 (Serial Number 55).

Terry, Flew. (2002). New Media: An Introduction. Oxford University Press. 